\title{
The French language environment in Slovakia and the professional development tools for a French language teacher
}

\section{[Prostredie francuzskeho jazyka na Slovensku a nastroje profesijneho rozvoja pre ucitela francuzskeho jazyka]}

\author{
Eva Pupikova - Jana Birova
}

DOI: 10.18355/XL.2020.13.01.01

\begin{abstract}
The aim of this paper is to describe the contemporary situation and position of French in the context of education as well as possibilities of cooperation. Another objective is to describe, by analytical approach, the importance of portfolio creation as a tool for the professional development of a teacher of French or a foreign language teacher. The study also focuses on the conditions and negative aspects of its creation. We will also outline the possibilities of its use to represent the acquired professional competences of a foreign language teacher during the attestation examination, which resulted from the new legislative conditions.
\end{abstract}

Key words: innovated language policy, teacher portfolio, reflection, professional standard, professional competence of teacher

Anotácia: Ciel’om príspevku je opísat' súčasnú situáciu a pozíciu francúzskeho jazyka v kontexte vzdelávania a možnosti spolupráce. Ďalším ciel'om je analytickým prístupom opísat' význam tvorby portfólia pre učitel'a francúzskeho jazyka, ako nástroja na jeho profesijný rozvoj. $\mathrm{V}$ štúdii sa zameriavame aj na podmienky a negatívne stránky jeho tvorby. Načrtneme tiež možnosti jeho využitia na reprezentovanie dosiahnutých profesijných kompetencií učitel’a cudzieho jazyka počas atestačnej skúšky, ktoré vyplynuli z nových legislatívnych podmienok.

Kl'účové slová: inovovaná jazyková politika, portfólio učitel'a, reflexia, profesijný štandard, profesijné kompetencie učitel’a

\section{Úvod}

Článok je výsledkom analýz dokumentov. Je spracovaný a publikovaný pre učitel'ov francúzskeho jazyka na základe dobrej spolupráce Slovenskej asociácie učitel’ov francúzštiny a Metodicko-pedagogického centra $v$ Nitre. Je inštrumentom pre učitel'ov, ktorí sa chcú pripravit' na atestáciu alebo si zvýšit' kvalifikáciu v súlade s novým zákonom. Štúdia má viacero podkapitol. Najskôr prezentujeme prostredie, v ktorom sa učitel' francúzskeho na Slovensku orientuje. V d’alších kapitolách je predstavený návod, ako spracovat' portfólio.

\section{Jazyková politika}

V septembri 2019 Centrum vedecko-technických informácií SR realizovalo prieskum na základných a stredných školách týkajúci sa vyučovania cudzích jazykov. Odsledovali sme zmeny. Možno konštatovat', že v roku 2019 (školský rok 2019-2020) aj napriek zmene jazykovej politiky, ktorá sa týka najmä zmeny k lepšiemu súvisiaca najmä so zvýšením počtu žiakov učiacich sa cudzí jazyk na základných školách, sa učí francúzsky jazyk iba v 38 základných školách, čo je z celkového počtu škôl 2091 iba $1,817 \%$. Zmena počtov v súvislosti so zmenou jazykovej politiky sa teda dostaví budúci rok alebo ten d'alší.

Ak by sme robili prieskum v počte žiakov na základných a stredných školách, máme $\mathrm{k}$ dispozícii tieto štatistické údaje od roku 2013. 


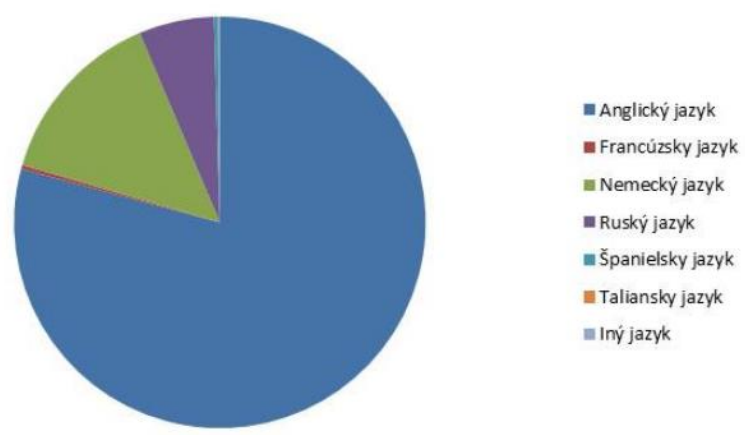

Graf 1 Cudzie jazyky na základných školách v roku 2019 (počty žiakov)

\begin{tabular}{|l|r|}
\hline & \multicolumn{1}{|c|}{$\mathbf{2 0 1 9}$} \\
\hline Anglický jazyk & 415375 \\
\hline Francúzsky jazyk & $\mathbf{1 6 1 6}$ \\
\hline Nemecký jazyk & 74120 \\
\hline Ruský jazyk & 31005 \\
\hline Španielsky jazyk & 1736 \\
\hline Taliansky jazyk & 160 \\
\hline Iný jazyk & 499 \\
\hline
\end{tabular}

Tabul'ka 1 Cudzie jazyky na základných školách v roku 2019 (počty žiakov)

\begin{tabular}{|l|r|r|r|r|r|}
\hline & \multicolumn{1}{|c|}{$\mathbf{2 0 1 3}$} & \multicolumn{1}{c|}{$\mathbf{2 0 1 6}$} & \multicolumn{1}{c|}{$\mathbf{2 0 1 7}$} & \multicolumn{1}{c|}{$\mathbf{2 0 1 8}$} & \multicolumn{1}{c|}{$\mathbf{2 0 1 9}$} \\
\hline Anglický jazyk & 382363 & 390292 & 399044 & 406806 & 415375 \\
\hline $\begin{array}{l}\text { Francúzsky } \\
\text { jazyk }\end{array}$ & $\mathbf{4 6 0 6}$ & $\mathbf{2 7 3 6}$ & $\mathbf{2 0 5 2}$ & $\mathbf{1 9 8 9}$ & $\mathbf{1 6 1 6}$ \\
\hline Nemecký jazyk & 126804 & 94507 & 87757 & 80979 & 74120 \\
\hline Ruský jazyk & 50418 & 38031 & 35389 & 32554 & 31005 \\
\hline $\begin{array}{l}\text { Spanielsky } \\
\text { jazyk }\end{array}$ & 1179 & 1165 & 1308 & 1628 & 1736 \\
\hline Taliansky jazyk & 190 & 160 & 166 & 179 & 160 \\
\hline Iný jazyk & 268 & 199 & 207 & 296 & 499 \\
\hline
\end{tabular}

Tabul'ka 2 Cudzie jazyky na základných školách 2013 - 2019 (počty žiakov)

Pozícia francúzskeho jazyka sa v roku 2019 dostala na 5. priečku v počte žiakov učiacich sa tento jazyk na ZŠ. Do roku 2018 obsadzoval tento jazyk 4. priečku. Demografická krivka, ktorá narástla za posledných 6 rokov o niekol'ko desat'tisíc žiakov, nemá vplyv na nárast počtu žiakov v jednotlivých jazykoch. Priamymi vplyvmi sú zmena jazykovej politiky, politika obsadzovania miest proporčne kvalifikovanými pedagógmi cudzích jazykov tak, aby sa zatraktívnila samotná škola a aby sa dodržali kritériá diverzity a pestrosti cudzích jazykov. Ďalším vplyvom je zastúpenie a motivácia učitel'ov francúzskeho jazyka na jednotlivých školách, podpora tohto jazyka riaditel'mi škôl a osveta medzi rodičmi, že varieta cudzích jazykov v multikultúrnej a mnohojazyčnej Európe je pre všeobecný sociálny a ekonomický prospech krajín, ktoré ju tvoria.

\section{Cudzie jazyky na stredných školách v priebehu posledných rokov}

XLinguae, Volume 13 Issue 1, January 2020, ISSN 1337-8384, ISSN 2453-711X 


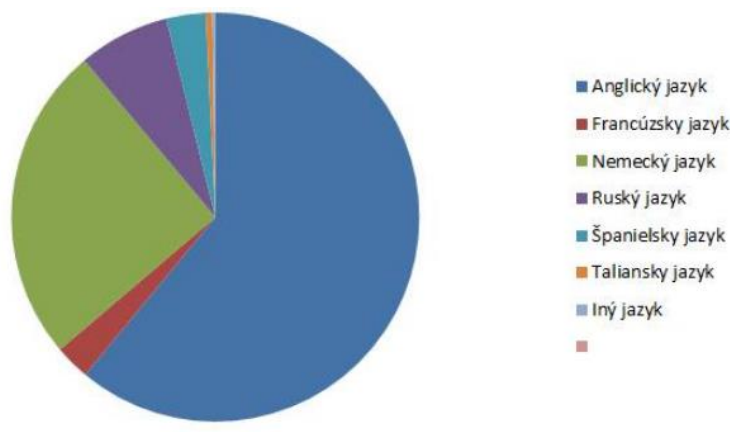

Graf 2 Cudzie jazyky na stredných školách v roku 2019 (počty žiakov)

\begin{tabular}{|l|r|}
\hline & \multicolumn{1}{|c|}{$\mathbf{2 0 1 9}$} \\
\hline Anglický jazyk & 183479 \\
\hline Francúzsky jazyk & $\mathbf{8 3 3 6}$ \\
\hline Nemecký jazyk & 75488 \\
\hline Ruský jazyk & 21736 \\
\hline Španielsky jazyk & 9412 \\
\hline Taliansky jazyk & 1535 \\
\hline Iný jazyk & 723 \\
\hline
\end{tabular}

Tabul'ka 3 Cudzie jazyky na stredných školách v roku 2019 (počty žiakov)

\begin{tabular}{|l|r|r|r|r|r|}
\hline & \multicolumn{1}{|c|}{$\mathbf{2 0 1 3}$} & \multicolumn{1}{c|}{$\mathbf{2 0 1 6}$} & \multicolumn{1}{c|}{$\mathbf{2 0 1 7}$} & \multicolumn{1}{c|}{$\mathbf{2 0 1 8}$} & \multicolumn{1}{c|}{$\mathbf{2 0 1 9}$} \\
\hline Anglický jazyk & 206105 & 190069 & 189392 & 186543 & 183479 \\
\hline $\begin{array}{l}\text { Francúzsky } \\
\text { jazyk }\end{array}$ & $\mathbf{1 4 3 8 6}$ & $\mathbf{9 0 9 7}$ & $\mathbf{9 1 6 2}$ & $\mathbf{8 4 2 2}$ & $\mathbf{8 3 3 6}$ \\
\hline Nemecký jazyk & 119578 & 89054 & 85289 & 80040 & 75488 \\
\hline Ruský jazyk & 30218 & 25040 & 24565 & 23298 & 21736 \\
\hline Spanielsky jazyk & 9289 & 7990 & 8584 & 9179 & 9412 \\
\hline Taliansky jazyk & 2334 & 1771 & 1804 & 1766 & 1535 \\
\hline Iný jazyk & 846 & 691 & 707 & 724 & 723 \\
\hline
\end{tabular}

Tabul'ka 4 Cudzie jazyky na stredných školách 2013 - 2019 (počty žiakov)

Na stredných školách a gymnáziách takisto klesol záujem, ale aj možnosti učit’ sa francúzsky jazyk. Od roku 2013 je to strata v počte o 6000 študentov na stredných školách.

\section{Prostredie francúzskeho jazyka a spolupráca}

Francúzština na Slovensku je prítomná na viacerých národných a nadnárodných úrovniach. Okrem základných, stredných, súkromných škôl je zastúpená v menšom počte aj na 8-ročných gymnáziách. Francúzština svojou výnimočnost'ou je zriedkavým jazykom, čo z nej robí jedinečnú, niekedy nedosiahnutel'nú métu, so záujmom dobíjat' sa k nej a pátrat'. Siet' organizácií zabezpečuje pre každé odvetvie potrebné náležitosti. Zo slovenských organizácií možno spomenút' Ministerstvo školstva, vedy výskumu a športu SR, Štátny pedagogický ústav, Metodickopedagogické centrum, ktorí dodávajú aj vd’aka spätnej väzbe od Slovenskej asociácie učitel'ov francúzštiny informácie o stave francúzštiny v teréne, a aj tým dokážu tvorit' zásadné legislatívne normy. Autentickost' výučby a kontakt s reálnym svetom frankofónie predstavujú nezastupitel'né inštitúcie Francúzske vel'vyslanectvo, Francúzsky inštitút na Slovensku, Francúzska aliancia v Banskej Bystrici, Francúzska 
aliancia v Košiciach a iné organizácie propagujúce francúzsky jazyka kultúru dôležité pre frankofóniu ako napríklad najstaršia a najdôležitejšia Slovenská asociácia učitel'ov francúzštiny (SAUF), združenia FRASK v Žiline alebo Bratislava accueil v Bratislave či IUFS v Banskej Bystrici. Existuje vyše 20 registrovaných spoločností priatel'ov Francúzska v jednotlivých slovenských mestách, ktoré podl'a svojej disponibility ponúkajú programy týkajúce sa francúzskej kultúry, nie však pravidelne ako vyššie spomínané, plne fungujúce inštitúcie.

Čo sa týka aktivít, ktoré oživujú a pripomínajú každý rok frankofóniu, možno spomenút' oslavy frankofónie $\mathrm{v}$ mesiaci marec, kultúrne aktivity a akcie poriadané Francúzskym inštitútom, Francúzskym vel'vyslanectvo a francúzskymi alianciami v spolupráci s množstvo rozličných inštitúcií. Ďalej sú to rôzne akreditované vzdelávania, profesijný rozvoj učitel'ov francúzštiny prostredníctvom aktualizačných, adaptačných alebo inovačných vzdelávaní, stáže, ktoré ponúka Francúzsky inštitút alebo SAIA, stáže a projekty Erasmus plus, rôzne sútaže pre frankofónov organizované Francúzskym inštitútom alebo francúzskymi alianciami či sútaže pre žiakov organizované Slovenskou asociáciou učitel'ov francúzštiny alebo sút’aže pre vysokoškolských študentov organizované asociáciou Francavis. Netreba zabudnút spomenút' aj iniciatívy pre študentov ako napríklad Simulácia európskeho parlamentu každoročne pripravovaná Francúzskym inštitútom v spolupráci s IUFS a Sciences Po v Dijone alebo aktivita ZAMUN na bilingválnom gymnáziu v Žiline, v ktorej ide o simuláciu OSN alebo olympiády vo francúzskom jazyku organizované Iuventou v spolupráci so SAUF. Niektoré aktivity pripravujú už aj samotní študenti, napríklad bohaté aktivity Francúzskej aliancie v Banskej Bystrici alebo Rádio pre francúzštinárov v spolupráci s UKF v Nitre a UMB v Banskej Bystrici. Každoročne je možné ukázat' svoj talent $\mathrm{v}$ kreatívnom písaní, sút'až organizovaná SAUF alebo v spievaní s názvom Spievam po francúzsky organizovaná Francúzskou alianciou (založená v 90. rokoch minulého storočia asociáciou SAUF). Sútaže majú väčšinou medzinárodný výstup a širší motivačný, náučný a kontaktný dopad na školy, ktorých žiaci sa zapájajú. Aktivity sú prevažne všetky financované projektmi podanými na Francúzskom inštitúte a Francúzskom vel'vyslanectve vd'aka Ministerstvu zahraničných vecí FR alebo belgickou asociáciou na podpory francúzštiny WBI či vedeckou agentúrou pre podporu frankofónie AUF.

Čo sa týka možností štúdia na vysokej škole na Slovensku, tieto univerzity ponúkajú varietu študijných programov s francúzskym jazykom:

Univerzita sv. Cyrila a Metoda v Trnave, Univerzita Matej Bela v Banskej Bystrici, Univerzita Komenského v Bratislave, Univerzita Konštantína Filozofa v Nitre, Prešovská univerzita v Prešove, Univerzita P. J. Šafárika v Košiciach. Viac informácií na stránkach IUFS alebo Francúzskeho inštitútu či Ministerstva školstva, vedy, výskumu a športu SR.

Vedecké činnosti sú podporované väčšinou projektmi APVV alebo projektmi Štefánik, Erasmus plus alebo inými zahraničnými schémami, priamym požiadaním na Francúzskom inštitúte alebo samoplatbou či sponzorskými darmi. Projekty KEGA, VEGA sú za momentálnych podmienok viac nedosiahnutel'né ako dosiahnutel'né.

$\mathrm{Na}$ podporu vedy $\mathrm{v}$ oblasti francúzskeho jazyka na Slovensku vznikol časopis XLinguae, ktorý každoročne publikuje jedno číslo venované francúzskemu jazyku. Výskumní pracovníci či vysokoškolskí učitelia, najskôr však dekanáty fakúlt, tak majú profit či už vedecký alebo finančný za publikáciu v indexovanom časopise. Určitý počet publikácií $\mathrm{v}$ takýchto časopisoch je potrebný aj k akreditácii študijných programov či k zvyšovaniu kvalifikácie. Na podporu vedy voblasti lingvistiky a aplikovanej lingvistiky sa dňa 6. decembra 2019 konalo 1. vedecké stretnutie asociácií cudzích jazykov, na ktorom sa vytvorila siet' výskumníkov v oblasti

XLinguae, Volume 13 Issue 1, January 2020, ISSN 1337-8384, ISSN 2453-711X 
lingvistiky a aplikovanej lingvistiky. Ciel’om vytvorenia siete je lepšia výmena vedomostí z oblasti metodológie výskumu, napríklad postupy používané v španielskej lexikológii pre meranie frekvencie alebo metóda kolektívnej autokonfrontácie definovaná francúzskymi odborníkmi, atd’. Stretnutia sa zúčastnili Jana Bírová, prezidentka SAUF, Jana Bérešová, prezidentka SAUA-SATE, Monica Sanchez, prezidentka SAUS, Mária Spišiaková, SAUS a Roman Kvapil, viceprezident SSRS Ich štúdie boli zahrnuté do tohto čísla, ked’že vychádzajú zo spolupráce so SAUF.

\section{Profesijné vzdelávanie učitel'ov}

Nielen pre učitel'ov francúzskeho jazyka, ale pre všetkých učitel'ov vošiel do platnosti Nový zákon o pedagogických zamestnancoch a odborných zamestnancoch ${ }^{1}$ v Slovenskej republike (platný od 1.9.2019), ktorý zavádza do učitel'skej praxe niekol'ko noviniek. Jednou z nich je portfólio, ktoré je potrebné pri vykonávaní atestačnej skúšky a postupov učitel'ov na vyšší kariérny stupeň. Desat' rokov využívania písomných atestačných prác nahradil nástroj, ktorým by mal učitel' praktickým spôsobom, preukazovat' dosiahnutie svojich profesijných kompetencií. Tvorba a prezentácia portfólia je podl'a novej legislatívy hlavným krokom potrebným k postupu na vyšší kariérny stupeň. Takto vnímané portfólio však stráca potenciálu nástroja na formovanie identity učitel'a. Odborné zdroje vyzdvihujú prínos portfólia ako flexibilného, stručného a autentického spôsobu rozvoja a hodnotenia jednotlivca a jeho kompetencie (Imhof a Picard 2009). Vnímanie učitel'ského portfólia „iba“ ako nástroja na prezentovanie dosiahnutých kompetencií počas atestačnej skúšky by spôsobilo vel’mi jednostranné a neúplné nazeranie na uvedený nástroj. Zámerom tohto príspevku je prezentovanie významu využívania samotného nástroja portfólia v pedagogickej praxi učitel'ov cudzích jazykov.

\section{Význam portfólia v profesijnom rozvoji učitel’a}

Lexikálny význam pojmu portfólio pochádza z ekonomických sfér. Označuje portfólio (z tal. - dosky na spisy alebo listiny) ako určitú zostavu, súbor akcií a iných cenných papierov v majetku jedného investora. V súvislosti s portfóliom žiakov, alebo učitel'ov ide o zbierku, kolekciu, súbor produktov, dokumentov, artefaktov, predmetov. Ak chceme plne pochopit' význam portfólia v učitel'skom prostredí, je nutné pozriet' sa na portfólio z niekol'kých uhlov pohl'adu. Konkrétne ich zhrnuli H. Barrett a J. Carney (2005) podl'a E. Hartnell-Younga, M. Morrissa. Hovoria o troch hlavných významoch portfólia: vzdelávacie (formatívne) portfólio, ktoré sa zvyčajne vyskytuje priebežne na podporu profesionálneho rozvoja; posudzovacie (sumatívne) - portfóliá, ktoré sa zvyčajne vyskytuje $\mathrm{v}$ kontexte formálneho hodnotiaceho procesu; zamestnanecké (marketingové) portfóliá, ktoré sa používajú na hl'adanie zamestnania. Za najrozsiahlejšie (množstvo) považujeme pracovné portfólio, ktoré sa tvorí prirodzeným spôsobom zhromažd’ovaním rôznych materiálov k vyučovaciemu procesu. Učitel' cudzích jazykov počas svojej praxe zbiera svoje produkty, pomôcky, ktoré využíva vo svojej edukačnej činnosti. Ak učitel' súčasne reflektuje tvorbu obsahu portfólia, už môžeme portfólio považovat' za vzdelávací prostriedok v zmysle konštruktivistických princípov. Učitel' konštruuje svoje vlastné poznanie prostredníctvom vlastných skúseností. Reflektovaním produktov v portfóliu sa učitel' spätne vracia $\mathrm{k}$ ich tvorbe, využitiu, významu a podl'a potreby revidovaniu. Počas profesijného života učitel'a sa objavujú míl'niky, kedy učitel' z reflexívneho portfólia vyberá produkty, ktoré mu poslúžia ako prezentácia jeho dosiahnutých kompetencií. Demonštrácia dosiahnutých ciel'ov v určitej oblasti učenia sa v určitej situácii stáva prezentáciou a nástrojom k hodnoteniu učitel’a pomocou prezentačného

\footnotetext{
1 ZÁKON 138/2019 z 10. mája 2019 o pedagogických zamestnancoch a odborných zamestnancoch a o zmene a doplnení niektorých zákonov https://www.slov-lex.sk/pravnepredpisy/SK/ZZ/2019/138/20191015
} 
(posudzovacieho) portfólia. Vytvorenie portfólia na účely prezentovania vlastného majstrovstva je prospešné pre učitel'a aj zo psychologického hladiska. Tento krok vedie k tvorbe vnútornej motivácie zlepšovat' svoje zaužívané kroky v edukácii. Motivačná funkcia je zosobnená vykonaním sumatívneho hodnotenia, napr. na atestačnej skúške, alebo pri hodnotiacom rozhovore.

Portfóliom učitel'a cudzieho jazyka môžeme nazvat' vel'mi bohatý súbor najrôznejších produktov alebo aj vel'mi tenkú, starostlivo vybranú zbierku najlepších dôkazov práce. Portfólio môže zahŕňat' činnost' učitel'a v jednej oblasti počas niekol'kých mesiacov alebo môže byt' vyvrcholením niekol'kých rokov jeho praxe. Portfólio môžeme vnímat' do značnej miery ako formu alternatívneho, autonómneho hodnotenia. Dôraz sa kladie na metauznávanie a sebahodnotenie. Učitel' zarad'uje do portfólia kvalitné „výrobky“ a správnou reflexiou zvyšuje svoje sebavedomie. Rôznorodost' formy, obsahu, ciel'ov a nazeranie na využitie portfólia st'ažuje univerzálnu definíciu tohto konštruktu. D. Kostrub a E. Severini (2016) uvádzajú, že portfólio je súbor produktov učitel'a, dôležitých informácií dokumentujúcich individuálny rozvoj jednotlivca, prostredníctvom ktorého je možná celková reflexia jeho rozvoja za určité časové obdobie. Ide o flexibilný, stručný a autentický spôsob rozvoja a hodnotenia jednotlivca a jeho profesijných kompetencií (Imhof a Picard, 2009). Popkewitz (In Kostrub a Severini, 2016) definuje portfólio ako kolekciu dôkazov rôzneho typu, je to konštruovanie a reflektovanie biografie na báze externej pamäte, reprezentuje procesy, špecifické nástroje pre dokumentovanie spôsobilostí, poznania a d'alších dispozícií. Dôraz na individuálnu učebnú stratégiu kladie C. J. Foote (2001). Portfólio považuje za vhodný spôsob dokumentovania individuálnej učebnej histórie. Učitel' si individuálnym spôsobom sumarizuje a dokumentuje svoje pokroky, ale aj neúspechy. Portfólio je viac než prepracovaný album alebo súbor písaných dokumentov: je to individualizovaný portrét učitel'a - profesionála reflektujúceho svoju filozofiu a prax. Tento portrét je úplne realizovaný prostredníctvom učitel'ovho uvážlivého výberu artefaktov a premyslenej reflexie týchto artefaktov, ktoré poskytujú výhl'ad do učitel'ovho profesijného rastu, uvádza B. Painter (In Píšová, 2007). Za portfólio A. Beka a D. Gllareva (2016) považujú organizovanú zbierku, ktorá pozostáva $\mathrm{z}$ artefaktov, ktorých ciel’om je poskytnút' autentický záznam, ktorý sa týka postavenia jednotlivca, najmä spojených s učením, hoci sa môže vzt'ahovat' aj na iné oblasti. Obdobne H. Barrett a J. Carney (2005) uvádza, že je to zbierka autentických a rozmanitých dôkazov, získaných z väčšej časti $\mathrm{z}$ archívu, ktorý predstavuje to, čo sa učitel' v priebehu času dozvedel, na ktorých pracoval a bola navrhnutá na prezentáciu jednej alebo viacerých oblastí. Za vel'mi výstižné a obsiahle považujeme charakterizovanie portfólia R. G. Sakhievou et al. (2015). Uvedení autori konštatujú, že portfólio učitel'ov je prezentovanie skutočných úspechov učitel'a, ich akumulácia, registrácia, klasifikácia, hodnotenie. Je to prezentácia výsledkov vzdelávacích, diagnostických, metodických, výskumných, samovzdelávacích, spoločenských a iných činností učitel'a v určitom období, zobrazujúci ochotu pedagóga pre sebarealizáciu a sebarozvoj. Všetky prezentované definície majú spoločného menovatel'a. Je ním odkaz na materiálnu povahu dokumentu. Portfólio vnímame ako zámerne vytvorenú zbierku (resp. súbor, kolekciu) rôznych dôkazov (dokladov, produktov, artefaktov) o pedagogickej činnosti učitel'a. Jeho fyzické zostavenie môže byt' materiálne (zakladače, šanóny, obaly, a pod.) resp. elektronické. Materiálna povaha portfólia je teda mnohým učitel'om viacmenej známa. Z prezentovaných definícií však vyplýva podstatnejší fakt z hl'adiska rozvoja učitel'a a tým je reflexívna činnost' učitel'a, ktorá by mala byt' prítomná počas tvorby profesijného portfólia. Aby sme portfólio mohli označit' za prostriedok k rozvoju reflexného myslenia, je sebareflexia nad obsahom portfólia nevyhnutným podstatným rysom procesu tvorby portfólia. Iba v tomto momente možno hovorit' o portfóliu ako o nástroji na vzdelávanie sa. Učitel' má významnú kontrolu nad tým,

XLinguae, Volume 13 Issue 1, January 2020, ISSN 1337-8384, ISSN 2453-711X 
čo zahrnie a hodnotí v portfóliu, aké produkty zachytávajú jeho rozvoj a vzdelávanie. Učitelia skúmajú svoju prácu a uvažujú nad ňou, aby stanovili d’alšie ciele. Môžu sa obzriet' spät' na svoje snaženie a porovnávat' ich s neskoršími výsledkami, aby videli, ako sa zmenili. Učitelia môžu zdokumentovat' výber svojej stratégie výučby, skúmat' problémy vyskytujúce sa vo výučbe, zdôvodňovat' svoje reakcie alebo premýšl'at' o kultúrnom a historickom kontexte školského prostredia a o tom, ako to ovplyvňuje výchovu a vzdelávanie detí. Portfóliá môžu poskytnút' efektívny prostriedok zachytávajúci myslenie učitel'ov, monitorovanie kl'účových problémov a usmerňovat' ich v tom, ako evidovat' svoje nápady a zachytávat' ich revidovanie. M. Olson a J. Osbourne (1991: 78) poznamenal, že ,, hlavným dôvodom pre využitie portfólia vo vzdelávani učitelov sa zdá byt' potenciál pre rozvoj ich reflexivneho myslenia“. Portfólio sa javí ako optimálny prostriedok k rozvoju reflexívneho myslenia učitel'ov z toho dôvodu, že učitel' sa môže opriet' o zážitky z realizovania výchovnovzdelávacieho procesu. Pomocou reflektovania produktov v portfóliu je možné menit' zážitky na skúsenosti. Reflexia je prostriedkom na znovuprežívanie zážitku z vyučovania a získanie skúseností, aby sa zážitok dal pochopit', poučit' sa zo situácie a rozvíjat' nové porozumenia a ocenenia (Knapp, 1993). Koreň slova reflexie pochádza z latinského „reflectere“, čo znamená „odrážat' spät"،. Ako zrkadlo odráža fyzický obraz, tak aj odraz ako myšlienkový proces nám odráža naše zážitky. Prostredníctvom pojmového uchopenia zážitkov môžeme menit' zážitok na skúsenost'. Ak zážitok neprejde pojmovým uchopením a zvnútornením, vel'mi t’ažko možno hovorit' o skúsenostiach. Počas reflexie spájame rôzne súvislosti, ktoré sme počas samotného zážitku nemohli alebo nestihli postrehnút'. Prehodnocujeme opätovne situácie z edukačného procesu. Pri tvorbe portfólia je preferovaná písomná reflexívna činnost' učitel'a. Reflexívne písanie sa opiera o všeobecnú citlivost' učitel'a na kritické udalosti, schopnost' premýšl'at' o vlastnej úlohe v konflikte, o ochote prijat' chyby ako príležitosti na vzdelávanie, uvádzajú tiež M. Imhofa a Ch. Picarda (2009). Dokumentácia sa používa na prehĺbenie jednotlivých fáz tvorby portfólia s dôrazom na výsledok: určovanie kvality skúseností, ktoré z pohl'adu učitel'a môžu byt' dôležité pre reflexiu; a potrebné po zážitku (inkubačná doba), aby sa zachoval odraz o tom, čo sa stalo a čo by sa z toho mohol učitel' naučit', uvádza M. Szymańska (2015). Reflexia nám umožňuje vyvodit' závery z našich minulých zážitkov a vytvárat' nové poznatky, ktoré môžeme uplatnit' $v$ našich budúcich aktivitách. Na označenie reflexného procesu môžeme použit' synonymá: hodnotenie, diagnostikovanie, zváženie, premýšl'anie, analýza, atd'. Spoločným menovatel'om uvedených pojmov je, že ide o zámerný proces myslenia o predchádzajúcom zážitku, nápade alebo probléme. Čím viac času venujeme reflexii, tým väčší je potenciál učenia sa, porozumenia a získavania skúseností. Učitelia podl'a výskumu M. Imhofa a Ch. Picarda (2009) označujú za najdôležitejší moment práve komunikáciu s učiacim sa partnerom, za ktorou nasleduje dokumentácia, reflexia učitel'skej skúsenosti a následné stanovenie ciel’ov. V podobnom duchu V.M. Gámiz-Sánchez et al. (2016) uvádzajú, že najdôležitejšími prvkami sú komunikácia, spolupráca a reflexia, pričom reflexia je zároveň záväzkom $\mathrm{v}$ tom zmysle, že by mala informovat' o našich budúcich krokoch. Reflexia učitel'a prebieha často vel'mi intuitívnym spôsobom. Učitel' porovnáva seba samého v čase. Ako som sa zmenil? Čo som zlepšil? Ako som postupoval? Aký to malo dopad? A práve intuitívny spôsob nazerania na vlastné kritériá, pomocou ktorých samého seba hodnotíme, môže byt' jadrom konfliktu medzi portfóliom ako procesom=nástrojom na vzdelávanie sa učitel'a a portfóliom ako produktomvýsledkom=nástrojom na hodnotenie učitel'a. Reflexia nad tvorbou portfólia prebieha na úrovni metakognície, ale intenzívnejšie na úrovni sociálnych vzt’ahov v školských podmienkach. M. Clement a R. Vandenberghe (2000) zdôrazňujú, že práve kolegiálna pomoc je rovnocenným prostriedkom k profesijnému rozvoju ako napr. samoštúdium. Prostredníctvom kolegov a nadriadených môže učitel' získavat' pocit silnej spolupatričnosti ku komunite školy a k samotnému povolaniu učitel'. Portfólio teda 
možno chápat' ako nástroj na budovanie učitel'skej identity v rámci praxe. Byt' schopný zviditel'nit' svoju prax dôkazmi a vedomým premýšl’aním o nej prispieva k budovaniu učiacej sa komunity. Proces tvorby portfólia konkrétneho učitel'a napomáha pri tvorbe dynamiky prostredia školy ako učiacej sa komunite a príslušnosti ku komunite. Aby sa reflexia nad produktom nestratila, je dôležité, aby učitel' svoje postrehy, myšlienky zapísal $\mathrm{k}$ danému produktu. Vel'mi výstižne definuje portfólio M. Szymańska (2015). Konštatuje, že je to nástroj, ktorý kombinuje činnosti vyplývajúce z kolbovho cyklu učenia. Teoretické poznatky sa odzrkadl'ujú v sebapozorovaní a vaxi a následnej $\mathrm{v}$ samotnej reflexii jednotlivých produktov portfólia.

Pravidelnou a systematickou tvorbou portfólia v pedagogickej praxi sa plní hned' niekol'ko ciel'ov. R. G. Sakhieva et al. (2015) zdôrazňuje, že vedenie portfólia plní tieto ciele:

- $\quad$ motivuje učitel'ov, aby sa zlepšovali v oblasti odbornej činnosti;

- navrhuje individuálne stratégie osobného a profesionálneho rozvoja;

- monitoruje kvalitu odbornej činnosti učitel'a;

- pomáha tvorit' zdravú konkurenciu, medzi učitel'mi;

- $\quad$ zlepšuje podmienky pre účinnú profesionálnu kariéru;

- zabezpečuje nestrannost', periodicitu, otvorenost' hodnotenia učitel'ovej činnosti;

- $\quad$ zabezpečuje hodnotenie učitel'a potrebné k získaniu certifikácií učitel’ov;

- rozvíja zručnosti reflexných a hodnotiacich činností učitel'a.

Učitel' si pomocou portfólia sleduje dosiahnutie vlastných profesijných kompetencií. Vie si identifikovat' svoje silné a slabé stránky a na základe toho dokáže stanovit' vlastný plán profesijného rozvoja. Tvorbou a prezentovaním portfólia sa v školách vytvára priestor na vzájomné „zdravé“ porovnávanie sa učitel’ov. Tvorba a vedenie portfólia si vyžaduje vzájomné podporovanie sa učitel'ov, výmenu skúseností. Pomocou neho sa môže tvorit' prostredie zdravej konkurencie, ktoré vedie ku skvalitňovaniu samotnej edukačnej činnosti. Medzi hlavné funkcie portfólia učitel'ov zarad’uje R. G. Sakhieva et al. (2015) funkciu motivačnú, formujúcu - vzdelávaciu, projektívnu, reflexívnu.

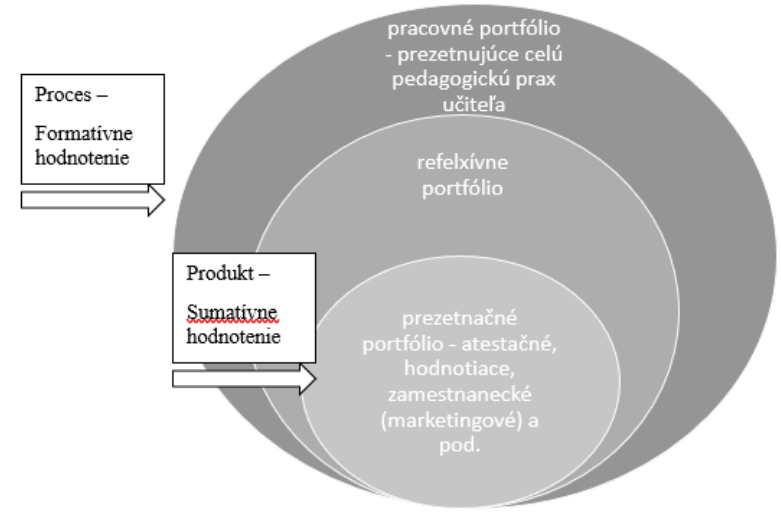

Obr. 1 Druhy portfólií v praxi učitel'a

Zdroj: Vlastné spracovanie

\section{Princípy tvorby portfólia}


Ako sme vyššie naznačili, tvorbu portfólia významne ovplyvňuje účel za akým ho učitel' začne tvorit'. Ideálnym stavom je, ak začína tvorit' svoje portfólio už pri nástupe do zamestnania. Sám si vyberá produkty do portfólia, pričom by nemal opomenút' práve reflexiu nad jednotlivými artefaktmi. Súčast'ou portfólia sú rôzne exponáty, ktoré zvyčajne zahŕňajú multimediálne záznamy o praxi, ktoré vybral sám. Spolu s rozšíreným komentárom, ktorý je súčast'ou každého exponátu odôvodňuje situáciu, ktorá nastala. V priebehu svojej praxe učitel' produkty z portfólia vyberá, redukuje, alebo mení a dopĺn̆a. Ak je v tomto procese prítomné reflexívne myslenie, učitel' projektuje svoje d'alšie pôsobenie a zároveň svoj profesijný rozvoj.

Kariérna cesta učitel'a cudzích jazykov môže obsahovat' viacero "míl'nikov“. Možnost' alebo povinnost' absolvovat' niektoré z nich je daná profesijným zákonom. Napr. učitel' prestupuje na vyššie kariérne stupne (samostatný PZ, PZ s 1. AS a PZ s 2.AS). Postup na vyšší kariérny stupeň možno považovat' za míl'nik, počas ktorého si učitel'a z pracovného portfólia vyberá a zostavuje produkty do prezentačného (atestačného) portfólia. Pomocou tejto zbierky môže preukázat' dosiahnutie profesijných kompetencií na určitej úrovni. Za iný míl'nik v rámci jedného školského roka možno považovat' aj hodnotiaci rozhovor na konci školského roka s vedúcim pedagogickým zamestnancom, počas ktorého učitel hodnotí dosiahnutie svojich kompetencií. Aj počas hodnotiaceho rozhovoru si učitel' môže pomôct' prezentačným portfóliom. Neopomenutel'ným medzníkom v kariére učitel'a môže byt' aj prestup na iné pracovné miesto. Pri všetkých uvedených udalostiach si učitel' môže pomôct' svojim profesijným portfóliom. Podl'a charakteru uvedenej epizódy si učitel' vyberá tie produkty, ktoré mu môžu najviac pomôct' v danej chvíli. Napr. pri hodnotiacom rozhovore môže učitel' prezentovat' dosiahnutie vel'mi konkrétnych ciel'ov v oblasti výchovy a vzdelávania. Samotné zostavenie atestačného portfólia je definované profesijným zákonom a vyhláškou 361/2019 o vzdelávaní v profesijnom rozvoji ${ }^{2}$. Ak má učitel' jasný pohl'ad na udalost', ktorá ho čaká môže pristúpit' k tvorbe prezentačného (resp. atestačného) portfólia. Profesijný zákon $\S 60$ uvádza, že atestačné portfólio je súbor dokladov o získaní profesijných kompetencií vyžadovaných pre zaradenie do vyššieho kariérového stupňa. Aby mohol učitel' cudzieho jazyka zostavit' uvedený súbor dokladov potrebuje poznat', aké profesijné kompetencie má dokladmi preukázat' a súčasne by mal poznat' niektoré princípy tvorby portfólia. Prvým princípom je poznanie a akceptovanie profesijného štandardu učitel'a ${ }^{3}$. Učitel' postupuje podl'a profesijných kompetencií, ktoré sú jeho súčastou. Profesijný štandard je zostavený bez ohl'adu na predmetovú aprobáciu učitel'a. Rozdiely v profesijných štandardoch existujú iba vzhl'adom k stupňu vzdelávania na ktorom učitel' pôsobí. Učitel' cudzích jazykov zostavuje svoje portfólio podl'a podkategórie, do ktorej je zaradený (učitel' pre druhý stupeň ZŠ, učitel' strednej školy). Súčastou profesijného štandardu sú tri oblasti, v rámci ktorých je definovaných 9 profesijných kompetencií. J. Průcha et al. (2009, s.409) označuje kompetenciu ako „receptívny pojem, ktorý vyjadruje komplex spôsobilostí (vedomostí, zručností, postojov, skúseností a pod.), ktorých základy si študent osvojuje $v$ pedagogickom vzdelávani a rozvíja vo svojej d’alšej kariére“. Ak uvažujeme o komplexnej spôsobilosti vykonávat' určitú profesiu môžeme hovorit' o profesijnej kompetencii. Profesijný štandard teda obsahuje 9 profesijných kompetencií, ktoré sú

\footnotetext{
${ }^{2}$ Vyhláška Ministerstva školstva, vedy, výskumu a športu Slovenskej republiky z 28. októbra 2019 o vzdelávaní v profesijnom rozvoji https://www.slov-lex.sk/pravnepredpisy/SK/ZZ/2019/361/20191115

${ }^{3}$ Pokyn ministra č. 39/2017, ktorým sa vydávajú profesijné štandardy pre jednotlivé kategórie a podkategórie pedagogických zamestnancov a odborných zamestnancov škôl a školských zariadeníhttps://www.minedu.sk/pokyn-ministra-c-392017-ktorym-sa-vydavaju-profesijnestandardy-pre-jednotlive-kategorie-a-podkategorie-pedagogickych-zamestnancov-a-odbornychzamestnancov-skol-a-skolskych-zariadeni/
} 
rozdelené do troch oblastí. Prvá oblast' je smerovaná k poznávaniu a diagnostikovaniu individuálnych charakteristík každého žiaka (vývinových, sociálnych, zdravotných a pod.). Druhá oblast' obsahuje kompetencie, ktoré súvisia so samotným vzdelávacím procesom. Učitel' by mal byt' schopný plánovat', realizovat', hodnotit' vyučovací proces. Predpokladom je samozrejme dokonalé ovládanie didaktiky výučby cudzieho jazyka. Tretia oblast' profesijného štandardu je oblast' plánovania a realizovania svojho vlastného profesijného rozvoja. Poznanie profesijných kompetencií, ktoré sú súčast'ou profesijného štandardu umožnia učitel'ovi vyberat' tie produkty, ktoré môžu dokladovat', že kompetenciu z profesijného štandardu dosiahol. Druhým princípom je komplexnost' hodnotenia. Súvisí s komplexným pohl'adom na jednotlivé produkty. Jeden produkt v portfóliu môže prezentovat' dosiahnutie hned' niekol'kých profesijných kompetencií (napr. plánovanie vyučovacej hodiny podl'a individuálnych špecifík žiakov v triede prezentuje, že učitel' dokáže identifikovat' individuálne špecifická diet'at'a a zároveň, dokáže podl'a zistení o žiakoch, vyučovací proces plánovat'). Tretím princípom je tzv. etický princíp, ktorým je rešpektovanie autorského práva - dodaný materiál je $\mathrm{v}$ zhode so skutočnost'ou. Ak vnímame portfólio ako proces k sebarozvoja učitel'a nie je dôvod mysliet' si, že učitel' bude do portfólia zarad'ovat' produkty, ktoré nie sú jeho duševným vlastníctvom. (Tento problém by však mohol nastat' pri tvorbe reprezentačného/atestačného portfólia). R. G. Sakhieva et al. (2015) hovorí o zásade nutnosti dodržat' kontinuitu. Poskytnutý materiál odráža dynamiku rozširovania činnosti učitel'a, profesionálny rast učitel'a v čase. Portfólio prezentuje časový vývin učitel'a ako profesionála. Učitel' môže prezentovat' svoj pokrok $\mathrm{v}$ určitých oblastiach. Nevyhnutným princípom pri tvorbe portfólia je aj aktuálnost' (optimálnost'). Nie je dôležitý samotný nástroj, teda portfólio, ale dôležité je zachytenie etapy, v ktorej prišlo k sebarozvoju učitel'a.

\begin{tabular}{|c|c|c|}
\hline & Portfólio ako proces učenia sa & Portfólio ako produkt \\
\hline Typ hodnotenia & $\begin{array}{l}\text { Formatívne - učitel' mení svoje } \\
\text { zauživané postupy }\end{array}$ & $\begin{array}{l}\text { Sumatívne }- \text { učitel' } \\
\text { prezentuje svoje postupy }\end{array}$ \\
\hline Účel & $\begin{array}{lll}\begin{array}{l}\text { Individuálny } \\
\text { portfólia }\end{array} & \text { zámer tvorby } \\
\end{array}$ & $\begin{array}{ll}\text { Daný } & \text { externými } \\
\text { podmienkami }\end{array}$ \\
\hline Produkty & $\begin{array}{l}\text { Individuálny výber podl'a } \\
\text { samotného učitel'a }\end{array}$ & Predpísané externe \\
\hline $\begin{array}{l}\text { Usporiadanie } \\
\text { produktov }\end{array}$ & $\begin{array}{l}\text { Učitel’ je ,architektom“ svojho } \\
\text { portfólia }\end{array}$ & predpísané externe \\
\hline $\begin{array}{l}\text { Posudzovanie } \\
\text { produktov }\end{array}$ & Kvalitatívne & Kvantitatívne, kvalitatívne \\
\hline $\begin{array}{l}\text { Dobra trvania- } \\
\text { Termín }\end{array}$ & Sústavne, priebežne & $\begin{array}{l}\text { Daný externe, zvyčajne } \\
\text { jeden termín za dlhšie } \\
\text { obdobie }\end{array}$ \\
\hline Reflexia & $\begin{array}{l}\text { Uvedomenie si pozitív aj } \\
\text { negatív, plánovanie zmeny }\end{array}$ & $\begin{array}{l}\text { Prezentovanie najmä } \\
\text { pozitív }\end{array}$ \\
\hline Motivácia & Podporuje vnútornú motiváciu & $\begin{array}{l}\text { Je podporovaný najmä } \\
\text { vonkajšiu motiváciou }\end{array}$ \\
\hline Publikum & $\begin{array}{l}\text { Sám učitel'a, kolegovia, rodina, } \\
\text { priatelia - podl'a vol'by učitel'a }\end{array}$ & Externé - dané \\
\hline $\begin{array}{l}\text { Požadované } \\
\text { vedomosti }\end{array}$ & $\begin{array}{l}\text { Učitel' ich získava priamo pri } \\
\text { procese tvorby portfólia }\end{array}$ & $\begin{array}{l}\text { Poznanie podmienok } \\
\text { tvorby portfólia }\end{array}$ \\
\hline
\end{tabular}

Tabul'ka 5 Porovnanie portfólia ako procesu a portfólia ako produktu

Zdroj: modifikované podl'a H. Barrett a J. Carney (2005)

XLinguae, Volume 13 Issue 1, January 2020, ISSN 1337-8384, ISSN 2453-711X 
Aké dokumenty môžu tvorit' (reprezentačné) portfólio učitel’a cudzieho jazyka?

V d'alšej časti načrtneme postup fyzického zostavovania portfólia. G. Sakhieva et al. (2015) uvádza, že úvod portfólia by mal tvorit' životopis učitel'a, spolu s dokumentmi, ktoré potvrdzujú vzdelanie učitel'a. Súčast'ou portfólia by mali byt' doklady o dosiahnutom vzdelávaní ale aj doklady o absolvovaní d’alšieho vzdelávania (certifikáty, diplomy, osvedčenia a pod.). Učitel' tým prezentuje, že dosiahol kompetencie súvisiace s plánovaním a realizovaním vlastného profesijného rozvoja. M. Valent (2019) uvádza, že d'alšou čast'ou portfólia je osobná vzdelávacia platforma (v tejto časti učitel' formuluje osobné východiská, filozofiu svojej pedagogickej činnosti, názory a postoje voči profesii). Učitel', podl'a M. Valenta (2019), prezentuje svoj názor na pedagogiku a prácu učitel'a, pohl'ad na rolu učitel'a, rolu žiaka a rolu rodiča, podhl'ad na posuny v kariére, víziu svojho pedagogického pôsobenia do budúcnosti. R. G. Sakhieva et al. (2015) hovorí o vzdelávacom kréde/náučnej eseji/vzdelávacej filozofii/ vzdelávacej koncepcie (v závislosti od skúsenosti učitel’a v oblasti vzdelávania). V tejto časti učitel' prezentuje svoje postoje k učitel'skému povolaniu, svoje názory na súčasné vzdelávanie. Ďalšie produkty súvisia s edukačným procesom. R. G. Sakhieva et al. (2015) konkretizuje, že súčast'ou môže byt' napr. program pre prácu s nadanými det'mi. Použité technológie, metódy a techniky; Informácie o vykonaných demonštračných lekciách a vykonaných majstrovských kurzoch (dátum, predmet, skupina, úroveň), u nás otvorené hodiny, metodické dni. Dôkazmi o realizácii edukačného procesu môžu byt' kópie analýzy a sebaanalýzy vyučovacích hodín.

L'intitulé de l'activité :

\begin{tabular}{|c|c|}
\hline OBJECTIFS: & $\begin{array}{l}\text { Les professeurs de français sauront élaborer des activités pour } \\
\text { éveiller à la langue française chez les enfants. }\end{array}$ \\
\hline $\begin{array}{l}\text { Compétences } \\
\text { Aptitudes }\end{array}$ & $\begin{array}{l}\text { compétences linguistiques et sociolinguistique, interculturel } \\
\text { Aptitudes : production écrite, production orale, réception audio- } \\
\text { visuelle, réception écrite, etc. }\end{array}$ \\
\hline ÉTAPE/DUREEE & ....... minutes \\
\hline DÉROULEMENT & Décrire les activités professeur et les activités élèves \\
\hline Auto-réflexion & $\begin{array}{l}\text { Analyses des points forts et faibles, des risques et des défis de la } \\
\text { mise en réalisation de } 1^{\prime} \text { activité. Se rédige après la mise en } \\
\text { réalisation. }\end{array}$ \\
\hline MATÉRIEL & Matériel élaboré doit être copiable. Collé ici. \\
\hline \multicolumn{2}{|c|}{$\begin{array}{l}\text { CONSIGNE } \\
\text { Lisez l'article. Soulignez les mots que vous ne comprennez pas et discutez en groupes. Après, } \\
\text { répondez auo questions suivantes: } \\
\text { 1. De quoi p } \\
\text { 2. Mmm } \\
\text { 3. } \mathrm{Nnn} \\
\text { 4. Bla bli }\end{array}$} \\
\hline \multicolumn{2}{|l|}{ Le texte } \\
\hline \multicolumn{2}{|l|}{ L'image } \\
\hline & \\
\hline Clé & \\
\hline
\end{tabular}

Obr. 2 Priprava hodiny a sebareflexia, analýza

Súčast'ou tiež môžu byt' dôkazy o lektorskej činnosti učitel'a v rámci metodického združenia školy, predmetovej komisie, výstupe na konferencii či vedenie workshopu. 
9:00 Petit-déjeuner

9:20 - 10:45 Hôtel KERLING, salle 101, présidente des sessions 3B, 4B : Sandrine Boussard-Nilly

Moussa, Ahmed - Lycée Mahalet Hassan, El-Gharbeya, Egypte : Atelier "découvertes" conçu pour épanouir vos élèves

Abbas, Ekramy - École secondaire pour les garcons, Motobas, Egypte : Utiliser les technologies aux méthodes de français

Hrnková, Adriana - École primaire, Hmciarska, Zvolen, Slovaquie : Activités ludiques

Suchovská, Miriam - Gymnázium Ladislava Novomeského, Senica, Slovaquie : Acirvités ludiques

Štefanková, Martina - ZŠ s MŠ Štefana Moysesa, Žiar nad Hronom, Slovaquie : Inventions des inventeurs

francophones

Vidová, Marianna - Stredná športová škola J. Herdu et Lycée J. Bottu, Trmava, Slovaquie : Activités ludiques

10:45 - 11:00 Pause-café

11:00 - 12:30 Hôtel KERIING, salle 101, présidente de la session 5B : Sandrine Boussard-Nilly

Gérôme, Rémi - Editions Didier-Hatier : Grandir et parler en français avec la méthode "Passe-passe"

Dudova, Olga - Lycée Jan Holly, Trmava : Activités ludiques

12:30 Rafraichissement, salle 101 : Vin mousseux sec et Fromage de la Farma pod Melichovou skalou

13:30 - 16:30 Hôtel KERIING, salle 101, présidente de la session 6B : Sandrine Boussard-Nilly

Bírová, Jana - Université Ss. Cyrille et Méthode, Trmava, Slovaquie : Intercompréhension entre les langues : choix du vocabulaire à caractère motivant et facilitateur

Jursová, Veronika - École francaise, Bratislava, Slovaquie : Activités ludiques

Vishocica, Suela - Lycée Mahmut et Ali Cungu, Albanie : Enseignement du français au lycée

Vranikovičová, Martina - Lycée Angely Merici. Trnava, Slovaquie : Activités ludiques

Zatková, Zita - Ecole primaire L'udovita Stúa, Sala, Slovaquie : Les jeux

Murčová, Katarina, École primaire Bratislava, Slovaquie : Activités ludiques

Soeur Tadea - Lycée, Bratislava, Slovaquie : Activités ludiques

Surhanáková, Xénia, Cadca, Slovaquie : Activités ludiques

Proksová, Natália - Lycée Trmava, Slovaquie : Activités ludiques

Klimešová, Mária, Bratislava, Slovaquie : Activités ludiques

Beltran, Julien - Ecole francaise, Bratislava, Slovaquie: Activités ludiques

Rošteková, Mária - Université Matej Bel, Banská Bystrica, Slovaquie : Acrivités ludiques

17:00 RUIN BAR, Programme Cap à l'est

21:00 Dîner solennel, Restaurant Prijemny oddych

\section{Obr. 3 Dôkazy o lektorskej činnosti či workshope}

Dôkazmi môže byt' monitorovanie kvality uskutočnených vzdelávaní samotnými žiakmi, výsledky účasti žiakov na sút’ažiach, olympiádach, SOŠ, festivaloch, koncertoch, akademických sút'ažiach, sút’ažiach, výstavy a samozrejme výsledky žiakov vo vyučovacom procese. Produktami do portfólia môžu byt' didaktické pomôcky v rámci predmetov (obrazový materiál, prezentácie, pracovné listy, literárne texty vlastnej tvorby a pod.), recenzie SOČ, publikačná činnost' učitel'a, prednášky na konferenciách na rôznych úrovniach a seminároch.

V súvislosti s tret'ou oblast'ou profesijného štandardu môže učitel' prezentovat' činnost' uvádzajúceho učitel'a, ako aj pomoc pri tvorbe portfólia iného učitel'a. Súčast'ou portfólia môžu byt' informácie o výskume. V našich podmienkach sú to výsledky akčného výskumu učitel’a, zoznam vedeckých publikácií. 

94911 Nitra

Je soussignée, $\mathbf{X Y}$, confirme que $\mathrm{XX}$ a contribué à l'organisation de la Conférence internationale conviviale II Méthodologies et recherches des (jeunes) chercheurs Français langue mondiale: didactique / linguistique / littérature qui a eu lieu à Turčianske Teplice, Slovaquie, du 7 au 9 décembre 2018, en tant que membre du comité organisateur.

\section{Obr. 4 Potvrdenia o účasti, certifikáty}

Prezentovaním kompetencií v tretej oblasti, ktorá uvádza kompetenciu Stotožnit' sa s profesijnou rolou a školou môžu byt' informácie o účasti na spoločenskej činnosti školy, informácie o dobrovol'níckych a charitatívnych činnostiach (charitatívne akcie a akcie pre postihnuté deti, siroty, deti migrantov, starších občanov, vojnových a pracovných veteránov a d’alšie dobrovol'né iniciatívy), informácie o spolupráci $\mathrm{s}$ rodičmi žiakov, usporiadanie vzdelávacích a vol'nočasových aktivít. Kompetencia Plánovat' a realizovat' svoj profesijný rast a sebarozvoj môže byt' dokladovaná informáciami o samovzdelávaní, zvyšovaní kvalifikácie, odbornej rekvalifikácii, recipročných návštevách na hodinách iných učitel'ov, dokladmi o aktívnej a pasívnej účasti na d’alšom vzdelávaní. Proces plánovania vlastného profesijného rozvoja môžu byt' stratégie d'alšieho rozvoja, ktoré by podl'a R. G. Sakhieva et al. (2015) mali byt' vel'mi konkrétne a termínované.

\begin{tabular}{|l|l|}
\hline \multicolumn{2}{|c|}{ Oblast' Žiak } \\
\hline Kompetencia & Možné dôkazy \\
\hline $\begin{array}{l}\text { Identifikovat' vývinové a individuálne } \\
\text { charakteristiky žiaka }\end{array}$ & $\begin{array}{l}\text { Vyhodnotenie a interpretácia dotazníkov, } \\
\text { rozhovorov, analýz produktov žiakov, } \\
\text { sociometrie; } \\
\begin{array}{l}\text { Identifikovat' psychologické a sociálne } \\
\text { faktory učenia sa žiaka }\end{array}\end{array}$ \\
\cline { 1 - 1 } $\begin{array}{l}\text { Identifikovat' sociokultúrny k kontext výsledkov pedagogickej } \\
\text { vývinu žiaka }\end{array}$ \\
\hline
\end{tabular}




\begin{tabular}{|l|l|}
\hline \multicolumn{2}{|c|}{ Oblast' Výchovno-vzdelávací proces } \\
\hline Kompetencia & Možné dôkazy \\
\hline Plánovat' a projektovat' vyučovanie & $\begin{array}{l}\text { Plánovanie vyučovania, príprava na } \\
\text { vyučovaciu jednotku, tematický plán, } \\
\text { atd'. }\end{array}$ \\
\hline Realizovat' vyučovanie & $\begin{array}{l}\text { Video z hodiny a následná sebareflexia, } \\
\text { atd'. }\end{array}$ \\
\hline $\begin{array}{l}\text { Hodnotit' priebeh a výsledky vyučovania } \\
\text { a učenia sa žiaka }\end{array}$ & $\begin{array}{l}\text { Analýza priebehu hodnotenia (metód, } \\
\text { foriem, stratégií); formulovanie kritérí } \\
\text { na hodnotenie žiakov, testy, atd'. }\end{array}$ \\
\hline Kompetencia & $\begin{array}{l}\text { Možné dókazy } \\
\text { a sebarozvoj }\end{array}$ \\
\hline Stotožnit' sa s profesijnou rolou a školou \\
$\begin{array}{l}\text { Osobný plán profesijného rozvoja, } \\
\text { osvedčenia o absolvovaní d'alšieho } \\
\text { vzdelávania, potvrdenia účasti na } \\
\text { konferenciách, seminároch a pod. }\end{array}$ \\
\hline $\begin{array}{l}\text { Realizovanie otvorenej hodiny, realizácia } \\
\text { metodických dní, vedenie MZ, PK, } \\
\text { uvádzanie začínajúceho PZ, vedenie } \\
\text { školského časopisu, spracovanie web } \\
\text { stránok, usporiadanie volnočasových } \\
\text { aktivít žiakov, atd'. }\end{array}$ \\
\hline
\end{tabular}

Tabul'ka 6 Námety na doklady do portfólia

Uvedené možné dôkazy sú iba námetmi, akými môžu učitelia jazykov prezentovat' dosiahnutie svojich profesijných kompetencií. Inšpirovali sme sa vo vel'kej miere M. Valentom (2019) a R. G. Sakhieva et al. (2015). Pedagogická prax prináša ovel’a viac priestoru na tvorivost' učitel'a aj pri zostavovaní portfólia a veríme, že pracovné portfóliá učitel'ov obsahujú niekol'konásobne vyšší počet dokladov, než aké sme uviedli obrázku 3.

\section{Posudzovanie portfólia}

\section{Externí posudzovatelia}

Ako sme už vyššie spomenuli tvorba a vedenie portfólia je dlhodobý proces, trvajúci počas celej profesijnej dráhy učitel'a. Portfólio by malo byt' zostavované tak, aby učitel'ovi v priebehu jeho kariéry poslúžilo na rôzne účely. Jeho tvorba a vedenie je plne v kompetencii samotného učitel'a. V prípade, že učitel' ašpiruje na postup na vyšší kariérny stupeň zostavuje portfólio v zmysle legislatívy. Zákon 138/2019 o pedagogických zamestnancoch a odborných zamestnancoch $\S 59$ hovorí o tom, že atestácia je štátne overenie profesijných kompetencií vymedzených profesijným štandardom pre príslušnú kategóriu a podkategóriu pedagogického zamestnanca, pre príslušný kariérový stupeň, získaných vzdelávaním, sebavzdelávaním alebo výkonom pracovnej činnosti. V $\S 60$ ods. 1 sa uvádza, že atestácia sa skladá z prípravy na atestačnú skúšku, ktorou je posúdenie atestačného portfólia a doplnenie atestačného portfólia, obhajoby atestačného portfólia a atestačnej skúšky. Posudzovanie a obhajoba portfólia tak následne prináleží externej organizácii poskytujúcej atestačné konanie. Jej ciel'om bude sumatívne hodnotenie dosiahnutých kompetencií učitel'a na základe dokladov v portfóliu. Posúdenie portfólia ako produktu na základe externých kritérií však môže byt' $\mathrm{v}$ protiklade s kritériami, ktoré si stanovil učitel'a sám. Nepoznanie explicitných a spoločných kritérií na hodnotenie portfólia môže viest' k hodnoteniam, ktoré odrážajú subjektívne vnímanie jednotlivých hodnotitel'ov, čo 
vedie $\mathrm{k}$ vel'kým rozdielom $\mathrm{v}$ hodnotení $\mathrm{v}$ rámci inštitúcií ale aj medzi učitel'mi (Schaaf et al., 2005). Dôvodom môže byt' aj skutočnost', že samotné posudzovanie dosiahnutých kompetencií si vyžaduje širokú škálu zručností a vedomostí posudzovatel'a.

Externé posudzovanie portfólia by malo splńnat' určité kritériá kvality. M. F. Schaaf et al. (2005) konštatujú, že hlavné kritériá kvality sú: spol'ahlivost', platnost' a prijatel'nost'. Spol'ahlivost' sa týka rozsahu stability medzi meraniami a medzi hodnotami. Ak ten istý hodnotitel' zopakuje hodnotenie po niekol'kých intervaloch týždňov, alebo ak portfólio hodnotí aj iný hodnotitel', posudky by sa nemali od seba vel'mi odlišovat'. Platnost' sa týka otázky, či posudzovanie je skutočne zamerané na konkrétnu kompetenciu alebo vykonanie úlohy. Prijatel'nost' sa týka objektívnosti, transparentnosti, rovnosti a rovnocennosti hodnotenia

Nástrojom, ktorý možno použit' na definovanie externých kritérií na posudzovanie dosiahnutých kompetencií je už spomínaný profesijný štandard učitel'a. Jeho definovaním v pokyne ministra školstva č. 39/2017 sa zjednotili požiadavky na konkrétne kategórie a podkategórie učitel'ov. Profesijný štandard obsahuje profesijné kompetencie, ktoré budú súčast'ou hodnotenia atestačného portfólia učitel'a. Ako sme už vyššie spomenuli, atestačné portfólio je súbor dokladov o získaní profesijných kompetencií vyžadovaných pre zaradenie do vyššieho kariérového stupňa. Jeho súčast'ou sú najmä doklady o získaní požadovaného stupňa a druhu vzdelania, doklady o absolvovaní programu vzdelávania, doklady preukazujúce tvorivú činnost' pedagogického zamestnanca alebo potvrdenie o využívaní vyžadovaných profesijných kompetencií získaných sebavzdelávaním alebo výkonom pracovnej činnosti, ktoré vydá riaditel', uvádza $\S 60$ profesijného zákona. Znamená to teda, že riaditel' ako prvý hodnotí dosiahnutie a využívanie profesijných kompetencií učitel'a. Nástrojom môže byt' portfólio. Alternatívnym spôsobom na hodnotenie a sebahodnotenie učitel'a je $\mathrm{v}$ tiež hospitácia. Výhodou tohto druhu externého hodnotenia je (v porovnaní so zostavovaním portfólia) časová nenáročnost', uvádzajú M. Wilson et al. (2014). Avšak jej využívanie (čiže externé pozorovanie činnosti učitel'a) neumožňuje učitel'om mat' kontrolu nad tým, kedy a čo je pozorované. Na rozdiel od portfólia, ktoré je výsledkom reflexívnej činnosti učitel'a.

\section{Problematické miesta so zavedením portfólia}

Načrtnutie rôzneho nazerania na portfólio ako procesu (prostriedok na učenie sa učitel'ov) alebo portfólia ako produktu (prostriedok na prezentovanie dosiahnutia kompetencií) však nie je jediným problematickým miestom pri zavádzaní portfólia do praxe učitel'ov. Zavedenie portfólia do praxe môžu sprevádzat' iné problematické situácie na rôznych etapách jeho tvorby. D. P. Berrill a E. Addison (2010) uvádzajú, že môžu nastat' konflikty pri stanovovaní ciel'ov, ako aj v samotnom procese zbierania dokladov. Posúdenie prezentačného (atestačného) portfólia môže byt' v protiklade so vzdelávacím (profesijným) portfóliom, pretože nie je jasné, či sú tieto reflexívne záznamy určené na účely postupu na vyšší kariérny stupeň, alebo na účely zlepšovania praxe. Ako uvádzajú H. Barrett a J. Carney (2005) autorovi prezentačného portfólia môžu obavy bránit' $\mathrm{v}$ úprimnej reflexii o jeho práci a selektívny charakter dôkazov znižuje hodnotu portfólia. D. P. Berrill a E. Addison (2010) z výskumov usudzujú, že môžu nastat' situácie, kedy učitel' vel'mi „rýchlo“ zozbiera produkty za účelom pozitívneho prezentovania seba samého pred externým hodnotitel'om, čo bude mat' vel'mi malý dopad na profesijný rozvoj učitel'a.

Problematické miesta portfólia monitorujú aj M. Imohof a Ch. Picard (2009). Vo svojom výskume, ktorého súbor tvorilo 144 učitel'ov, ktorí využívajú portfólio ako nástroj k profesijnému rozvoju, rezumujú niekol'ko výsledkov. $Z$ nich vyplynulo, že učitelia pred zavedením portfólia očakávajú komplexný text súvisiaci so zavedením portfóliového procesu. Mal by zahŕňat presné pokyny a zdôvodnenie zavedenia portfólia. Učitelia chceli mat' jasné predstavy o formalitách, obsahu. V prípade, že 
zavedeniu portfólia predchádza vzdelávanie považujú to za výhodu. Účastníci uvedenej štúdie sa st’ažovali na nedostatok spätnej väzby o tvorbe portfólií. Proces portfólia by mal byt' riadený komunikáciou s kolegami. Vyjadrili názor, že ak zostali položky portfólia prísne súkromné, motivácia k práci na nich postupne vybledla. Ak sa pozrieme na portfólio (prezentačné, atestačné), ako na produkt, potom je rizikom, že učitelia budú prezentovat' iba svoje silné stránky, čím sa vytratí autentické hodnotenie učitel'a a zachytenie pokroku. Ako d’alej M. Imohof a Ch. Picard (2009) prezentujú, forma písomnej reflexie, ktorú portfólio vyžaduje, považovali učitelia skôr za zjavnú výhodu. Neformálne poznámky k produktom v portfóliu ocenili ovel’a viac ako formálne spracovanie denníka. Účastníci výskumu ocenili ponechanie individuálnej stratégie učitel'a pri výbere formy spracovania portfólia a výbere komponentov. Objavila sa tiež obava, že ak boli pokyny na spracovanie portfólia príliš reštriktívne (napr. „napíšte dve stránky“), individuálna kreativita by sa obmedzila a tiež vnútorná motivácia investovat’ čas a úsilie.

\section{Záver}

Uvedomujeme si, že časové spracovanie portfólia je náročné. M. Imohof a Ch. Picard (2009) však uvádzajú, že portfólio ako nástroj na vzdelávania učitel'ov má zmysel. Dôležité však je, aby tvorba a vedenie portfólia nebolo pret’ažené očakávanou dokumentáciou. Implementovanie portfólií by nemalo zostat' v rovine zavedenia d’alšieho „bezvýznamného“ nástroja, ktorý budú považovat' učitelia iba ako d'alšiu zvláštnu požiadavku, ktorá si vyžaduje čas a úsilie. Vzniká riziko, že portfólio bude vel'mi násilne a cielene zostavované iba na účely postupu na vyšší kariérny stupeň. Takto chápané vedenie portfólia nemôže pomáhat's tvorbou vlastnej identity učitel'a a zvyšovania kvalít učitel'a. Portfólio by sa tak mohlo stat' iba d’alším zbytočným nástrojom, ktorý bude slúžit' len na krátkodobé prezentovanie sa učitel'a a dosiahnutie vonkajšieho ciel'a, prípadne d'alšej byrokratickej zát'aže učitel'ov. Dopíňame ešte, že problematickým miestom pri reflexívnom písaní môže byt' vel'mi často jazyk učitel'ov, ktorý používajú v prípade reflektovania pedagogických činností (Pupíková, Kollárová, 2017) a ktorý je vel’mi často jazykom laickým a nepedagogickým. Predídeniu týchto negatívnych predpokladov možno zabránit' niekol'kými opatreniami. Jedným z nich je napr. tvorba programu d’alšieho vzdelávania. Jeho obsahom by malo byt' nielen teoretické pochopenie „tvorby a významu portfólia“ ale aj snaha o vytvorenie pozitívneho postoja učitel'ov k pravidelnej a systematickej tvorbe portfólia. Dôležitým a nezanedbatel'ným je tiež konštituovanie kritérií hodnotenia portfólia v súvislosti od dosiahnutých profesijných kompetencií. Portfólio vnímame ako nástroj (stratégiu), pomocou ktorej učitel' reflektuje svoje pedagogické pôsobenie a na základe toho plánuje svoj sebarozvoj. Tak ako každá stratégia i táto si vyžaduje zručnost' pri jej využívaní, ktorú môžu učitelia získat' iba vlastnou praxou.

\section{Bibliographic references}

BARRETT, H. - CARNEY, J. 2005. Conflicting paradigms and competing purposes in electronic portfolio development. Available online: http://helenbarrett.com/portfolios/LEAJournalBarrett Carney.pdf .

BARRETT, H. C. 2005. Researching Electronic Portfolios and Learner Engagement: The REFLECT Initiative, Available online: http://electronicportfolios.com/index2.html BELYAEVA, I.G. - SAMORODOVA, E. A. - VORON, O. V. - ZAKIROVA, E. S. 2019. Analysis of Innovative Methods' Effectiveness in Teaching Foreign Languages for Special Purposes Used for the Formation of Future Specialists' Professional Competencies. In: Education Sciences. vol. 9, 171 p.

BEKA A. - GLLAREVA D. 2016. [online] The importance of using electronic portfolios in teachers work. In Peer-reviewed and Open access journal ISSN: 1804-4999, vol. 12, n. 1, pp.32-42. DOI: http://dx.doi.org/10.15208/ati.2016.03 
BERRILL D. P. - ADDISON E. 2010. Repertoires of practice: Re-framing teaching portfolios. In: Teaching and Teacher Education, n. 26, pp. 1178-1185 Available online: https://reader.elsevier.com/reader/sd/pii/S0742051X10000247?token=2572E7D17051607C 43795CF8C6B9EDF2D9CEA9484F4A7B3394A1A7C2279A0E932D4CEE648538904A0 58F9800AE3D2103

CLEMENT M. - VANDENBERGHE R. 2000. Teachers' professional development: a solitary or collegial (ad)venture? In: Teaching and Teacher Education, vol. 16, 2000, pp. 81-101.

DUCHOVICOVA, J. - TOMSIK, R. 2018. Managerial competencies of a teacher in the context of learners'critical thinking development: Exploratory factor analysis of a research tool and the results of the research. In: TEM Journal, vol. 7, n. 2., pp. 335-347.

FOOTE, C. J. 2001. Teaching portfolio 101: implementing the teaching portfolio inintroductory courses. In: Journal of Instructional Psychology, vol. 28, pp. 31-37.

FOURNIER, C. - GUILLET, S. - HALLAK, J. - PAPP, A. 2019. Teaching sustainbility: Notes from France. In: International Journal of Pluralism and Economics Education. vol. 10. n. 2, pp. 126-136.

GAMIZ-SANCHEZ, V. M. - GALLEGO-ARRUFAT, M. J. - CRISOL-MOYA, E. 2016. Impact of electronic portfolios on prospective teachers' participation, motivation and autonomous learning. In: Journal of Information Technology Education: Research, vol. 15, pp. 517-533. Available online: http://www.informingscience.org/Publications/3575

HANESOVA, D. - NELSON, A. - BADLEY, K. 2017. Educators in search of the fine line between use and misuse of new technologies. In: Communications - Scientific Letters of the University of Ziliny, vol. 19, n. 1., pp. 44-48.

HANESOVA, D. 2015. Move toward learner-centred foreign language pedagogy: Focusing on factors fostering language intake. In: XLinguae, Vol. 8. N. 4., pp. 46-59.

HANESOVA, D. 2015. Plurilingual and intercultural awarenessof future teachers. In: New educational review. vol. 42. n. 4., pp. 79-90.

HANESOVA, D. 2015. Evaluation of education and research at universities. In: New educational review. vol. 42. n. 4., pp. 279-281.

HARTNELL-YOUNG, E. - MORRISS, M. 1999. Digital Professional Portfolios for Change. Arlington Heights: Skylight Professional Development.

IMHOF M. - PICARD Ch. 2009. Views on using portfolio in teacher education. In:

Teaching and Teacher Education 25, pp. 149-15. Available online: www.elsevier.com/locate/tate

KNAPP D. W. 2013 Teaching as a Transformational Experience. In: Journal of Physical

Education, Recreation \& Dance. vol. 84, n. 6, pp. 42-47, DOI:

10.1080/07303084.2013.808129

KOSTRUB, D. - SEVERINI, E. 2016. Portfolio v pedagogickej praxi studenta Portfolio in educational practice of a student. In: Ucitelske praxe, p. 150.

KRALOVA, Z. - MALA, E. 2018. Teaching foreign languages in Slovakia. In: XLinguae. vol. 11, n. 4 , pp.11-21.

KRALOVA, Z. - TIRPAKOVA, A. 2019. Nonnative EFL Teachers'Speaking Anxiety: Post-Communist Country Context. In: SAGE Open. vol. 9, n. 2.

OLSON, M. - OSBOURNE, J. 1991. Learning to teach, the first year. In: Teaching and Teacher Education, vol 7, pp. 331-343.

PALOVA, M. - ZELENAKOVA, M. 2018. We Are Looking for Graduates with Professional Experience: Forum Students - Enterprises 2018 Offers a Solution to the Slovak Paradox. In: Politicke vedy. vol. 21, n. 2, pp. 203-210. ISSN 1335 - 2741.

PAYANT, C. - KIM, Y. 2019. Impact of task modality on collaborative dialogue among plurilingual learners: a classroom-based study. In: International Journal of Bilingual Education and Bilingualism. vol. 22. n. 5, pp. 614-627.

PISOVA, M. 2007. Portfolio v profesni priprave ucitele. Pardubice: Univerzita Pardubice. 154 p. ISBN 978-80-7395-024-8.

PISOVA, M. 2007. Portfolio v profesni priprave ucitele - otazniky, nadeje, nebezpeci In: Pisova, M.: PORTFOLIO v profesni príprave ucitele. Pardubice, pp.39-55, ISBN 978-807395-024-8 
POPKEWITZ, T. S. 2009. El cosmopolitismo y la era de la reforma escolar. Madrid: Morata.

PRUCHA, J., et al. 2009. Pedagogická encyklopedie. Prague: Portal, 936 p. ISBN 978-807367-546-2.

PUPIKOVA, E. - KOLLAROVA, D. 2017. Reflexia pedagogickej cinnosti ucitela materskej skoly. In: Predskolska vychova, vol. 2016/2017, n. 6, pp. 9-17. ISSN 00327220

ROSTEKOVA, M. 2018. Francuzsko-slovenska spolupraca ako motor internacionalizacie vysokoskolskeho vzdelavania na Slovensku. In: Politicke vedy. vol. 21, n. 1, pp. 204-211. ISSN $1335-2741$.

SAKHIEVA R. G. et. al. 2015. The Supplementary Education Teacher's Portfolio: Essence, Functions, Structure and Design Principles. In: Mediterranean Journal of Social Sciences, vol. 6, n. 2 DOI:10.5901/mjss.2015.v6n2s3p84 ISSN 2039-2117

SANZ ESPINAR, G. 2019. The task-based approach applied to the design of materials in the bilingual sections of French in the Community of Madrid. In: Cedille. vol. 15, pp. 497532.

SAUD, S. - WEDA, S. 2019. A comparative study of English and German syntactic variation by students at higher education: Evidence from complex predicates. In: Asian EFL Journal. vol 21. n. 2, pp. 176-195.

SCHAAF, M. F. - STOKKING, K. M. - VERLOOP, N. 2005. Studies in Educational Evaluation. Cognitive representations in raters' assessment of teacher portfolios vol. 31, n.1.

SZYMAŃSKA, M. 2015. Rola i znacz enie portfolio w kształceniu pedagogow. Kriakow: Akademia Ignatianum v Kriakowie, Available online: https://www.researchgate.net/profile/Maria_Szymanska/publication/319939212_Rola_i_zn aczenie_portfolio_w_ksztalceniu_pedagogow_Wlasna_koncepcja/links/59c27961458515af 3060b2f5/Rola-i-znaczenie-portfolio-w-ksztalceniu-pedagogow-Wlasna-koncepcja.pdf RIZEKOVA, I. 2018. Suppporting cotinuity in teaching French from secondary school to the university degree. In: XLinguae, vol. 11, n. 1XL, pp. 150-163.

RIZEKOVA, I. 2018. Linguistic and socio-cultural training of Slovak students for mobility in France. In: Synergies Europe, vol. 13, pp. 59-67.

VALENT, M. 2019. Portfolio ako prostriedok profesijneho rozvoja pedagogickeho zamestnanca (ucebny text). Bratislava: Metodicko-pedagogicke centrum,

WEDA, S. - SAKTI, A. E. F. 2018. Factors Influencing Students'Anxiety in Enflish as a Foreign Language Classroom. In: Journal of Physics: Conference Series. 1028 (1), 012100 .

WILSON, M. - HALlAM, P. J. - PECHEONE, R.L. - MOSS, P. A. 2014. [online] Evaluating the Validity of Portfolio Assessments for Licensure Decisions. In: Education Policy Analysis Archives, vol. 22, n. 6, http://dx.doi.org/10.14507/epaa.v22n6.2014

Words: 7232

Characters: 53708 (29,84 standard pages)

PaedDr. Eva Pupíková

Methodological center in Nitra

Faculty of Education

Constantine the Philosopher University in Nitra

Drazovska 4

94901 Nitra, Slovakia

Doc. Mgr. Jana Bírová, PhD.

Ss. Cyril and Methodius University

Faculty of Arts

Nám. J. Herdu 2

91701 Trnava, Slovakia

jana.birova@ucm.sk

XLinguae, Volume 13 Issue 1, January 2020, ISSN 1337-8384, ISSN 2453-711X 